\title{
ANALYSIS OF PROSPECTIVE PHYSICS TEACHER MISCONCEPTIONS ABOUT FRICTION FORCE WITH THREE TIER TESTS AND CLINICAL INTERVIEWS
}

\author{
Ahmad Busyairi* and Muhammad Zuhdi \\ Physics Education Department of Faculty of Teacher Training and Education, University of Mataram, \\ Mataram, Indonesia; \\ *Email: ahmad.busyairi@unram.ac.id
}

Accepted: November, 20 2020. Approved: November, 22 2020. Published: November, 222020

\begin{abstract}
A good and correct understanding of concepts is fundamental to prospective Physics teachers before graduating from college. Therefore, it is necessary to identify the concept to ensure that no students have misconceptions or understand the concept. This study aims at identifying the misconceptions experienced by prospective Physics teachers at the final level, especially in the friction force material. It is descriptive research conducted in a university in Mataram with 12 students involved. The instrument used was a three-tier test in a multiple-choice test with open reasons. A total of 10 items with 30 questions were used in this study. Data collection techniques used were tests and interviews. The data that has been collected was then analyzed using descriptive statistics. Based on the results of the data analysis, it was found that $46.29 \%$ of the students had misconceptions with details of $50.00 \%$ of the students experienced misconceptions in determining the type of friction force, $43.75 \%$ in determining the direction of friction force, and $47.22 \%$ in determining the magnitude of the friction force. The results of this study indicate that many students of prospective Physics teachers have misconceptions. Therefore, we need alternative learning that can be used to reduce the misconceptions had by future Physics teachers.
\end{abstract}

Keywords: misconception, prospective physics teacher, three-tier test, clinical interview

\section{INTRODUCTION}

The concept's position in learning Physics is very fundamental [1]. It is the basic structure used to build theories, principles, laws, models, and formulas in Physics. Without understanding the concept correctly, students will undoubtedly have difficulty understanding theories, rules, models, and formulas in Physics. For example, Newton's second law is built on reviewing the relationship between the concepts of force, mass, and acceleration. Similarly, Archimedes' law is built on the concept of lift and weight of displaced liquid. Therefore, the primary thing that students have to have when studying Physics is to understand Physics concepts correctly [2].

Before studying at school or university, essentially in students' cognitive structure, a conception of a specific concept has been embedded. This conception can arise from their observations of natural phenomena or cause by the information they get in the social environment in which they live [3]. Therefore, students' conceptions of certain concepts can be right or wrong according to the experiences and information in their daily living environment. Students' conceptions are valid if they follow scientists' or experts' conceptions. On the other hand, if the students' conceptions are not in accordance with the scientists' conceptions but they believe that their conceptions are correct, concept students can learn following conceptions [4-8].

Misconceptions in students are often found at school. It follows the results of previous studies that showed that there were still many high school students experiencing misconceptions [9-14]. Kaniawati's research results showed that $66.0 \%$ of students have misconceptions [15]. A total of $39.9 \%$ of students have misconceptions about light material [16]. In dynamic electricity, $26.2 \%$ of students have misconceptions [17]. Moreover, on the material of temperature and heat, $12.9 \%$ of students experienced misconceptions [18].

Many factors can cause misconceptions in students. One of the factors that can cause students to experience misconceptions is the teacher who teaches them in class [19]. The teacher's mistakes in teaching or even the wrong conception of the teacher can cause misconceptions in students. The teacher's false concept will be passed on to students to experience misconceptions automatically. These kinds of misconceptions are usually rather difficult to fix because students feel confident that the concepts taught by their teachers are correct [20]. Therefore, before teaching in the classroom, teachers should understand the concepts they will teach.

As the central learning resource in schools, teachers must be adequately prepared to have a good and correct understanding of concepts. One way that can be done is to prepare prospective teachers who are currently studying at the university level. As a first step, the researcher plans to conduct an analytical study to identify misconceptions that occur in prospective teachers. It is important to do as a basis for determining the proper treatment to overcome the problem. 
One of the instruments that can be used to identify misconceptions in students is to use diagnostic tests [21-22]. Many studies use diagnostic tests to identify misconceptions that occur in students [23-26]. Diagnostic tests are an evaluation tool to identify unresolved learning problems [27]. By using diagnostic tests, teachers can obtain pure ideas about students' understanding and difficulties faced. This information is then used as a basis for determining alternative teaching methods to overcome the problems experienced by these students [28]. One form of diagnostic test that is often used to identify misconceptions that occur in students is a three-tier test [29].

The three-tier test is a leveled multiple-choice test. The first level contains questions just like regular multiple-choice. The second level is a question to find out the students' arguments or reasons regarding their answers at the first level. The third level contains questions to determine students' confidence in their responses [30]. Questions at the third level are used to identify whether students have misconceptions or do not understand the concept. In general, three-tier tests are made in leveled multiplechoice tests. However, in this study, the second level of the three-tier test was made up of open-ended questions to give students the freedom to express their conceptions of certain concepts hoping that the information obtained is complete and more in-depth.

In addition to using the three-tier test, the researcher also conducted interviews with the prospective Physics teachers to obtain more in-depth data. It is in line with Gurel's statement that interview techniques can be used in investigations to get more detailed, comprehensive, and in-depth data, especially related to students' cognitive structures [30]. Interviews can provide more comprehensive information regarding students' conceptions of certain concepts [31].

\section{RESEARCH METHODS}

The method used in this study is the descriptive research method that aims to make a systematic and accurate description or description of the facts being investigated [32]. This study was conducted at a university in Mataram consisting of 12 prospective Physics teacher students in their final semester. Samples were taken using a simple random sampling technique. A simple random sampling technique is a sampling technique that is conducted randomly without regard to the existing strata in the population [33].

The data in this study were obtained by giving tests and interviews to students. The test instrument used was in the form of a three-tier test. The first level contains questions just like regular multiplechoice. The second level is a question to find out the students' arguments or reasons regarding their answers at the first level. The third level contains questions to determine students' confidence in their answers. A total of 30 questions made into ten questions were used in this study. The following is an example of a three-tier test used in this research.

1. Seorang anak mendorong lemari di atas lantai datar kasar seperti yang ditunjukkan gambar di samping. Jika lemari yang ia dorong tidak bergerak sama sekali maka ini menandakan bahwa....
A. Gaya dorong $<$ gaya gesek
B. Gaya dorong < gaya berat lemari
C. Gaya dorong = gaya gesek
D. Gaya dorong $\leq$ gaya gesek
E. Gaya dorong > gaya gesek

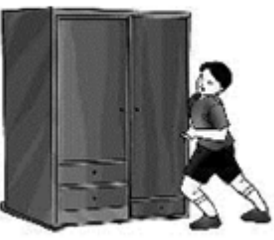

Berikan alasan:

Apakah anda yakin dengan jawaban tersebut.....
A. Yakin
B. Tidak yakin

Figure 1. Example of three-tier test questions

The research data were then identified, classified, and analyzed using descriptive statistics to determine the percentage of students who understood the concept, had a misconception and did not understand the concept. The guidelines for classifying conceptions in this study were adapted from Arslan's categorization guidelines [34].
In addition to using the three-tier test, the researchers also conducted interviews with the prospective Physics teachers. Interviews were conducted by finding their answers when they were given the three-tier test. It is aimed at obtaining more in-depth data related to the conception of the prospective Physics teachers. 
Table 1. Guidelines for categorizing the conception of prospective Physics teachers

\begin{tabular}{|c|c|c|c|c|c|c|c|}
\hline Answer & Code & Reason & Code & Certainty & Code & Category & Code \\
\hline True & $\mathrm{B}$ & True & $\mathrm{B}$ & Sure & $\mathrm{Y}$ & Understands concept & $\mathrm{UC}$ \\
\hline True & B & False & S & Sure & Y & Misconception & M \\
\hline False & S & True & B & Sure & Y & Misconception & M \\
\hline False & S & False & S & Sure & $\mathrm{Y}$ & Misconception & M \\
\hline True & B & True & B & Unsure & TY & Guesses & $\mathrm{G}$ \\
\hline True & B & False & $S$ & Unsure & TY & $\begin{array}{l}\text { Doesn't understand the } \\
\text { concept }\end{array}$ & DUC \\
\hline False & S & True & B & Unsure & TY & $\begin{array}{l}\text { Doesn't understand the } \\
\text { concept }\end{array}$ & DUC \\
\hline False & S & False & S & Unsure & TY & $\begin{array}{l}\text { Doesn't understand the } \\
\text { concept }\end{array}$ & DUC \\
\hline
\end{tabular}

\section{RESULTS AND DISCUSSIONS}

An overview of the conception of the prospective Physics teachers based on the data analysis that has been done is as follows.

From the graph above, it can be seen that $46.29 \%$ of the prospective Physics teacher students have misconceptions, $28.70 \%$ do not understand the concept, and only $25.00 \%$ of them understand the concept. It shows that many students still have misconceptions and do not even understand the concept even though they are in the final semester. It shows that the learning that has been done so far is still less effective in reducing misconceptions in students.

The misconceptions that mapping in students, classification the concept of friction force material into 3 (three) sub-concepts are needed as shown in the following table.

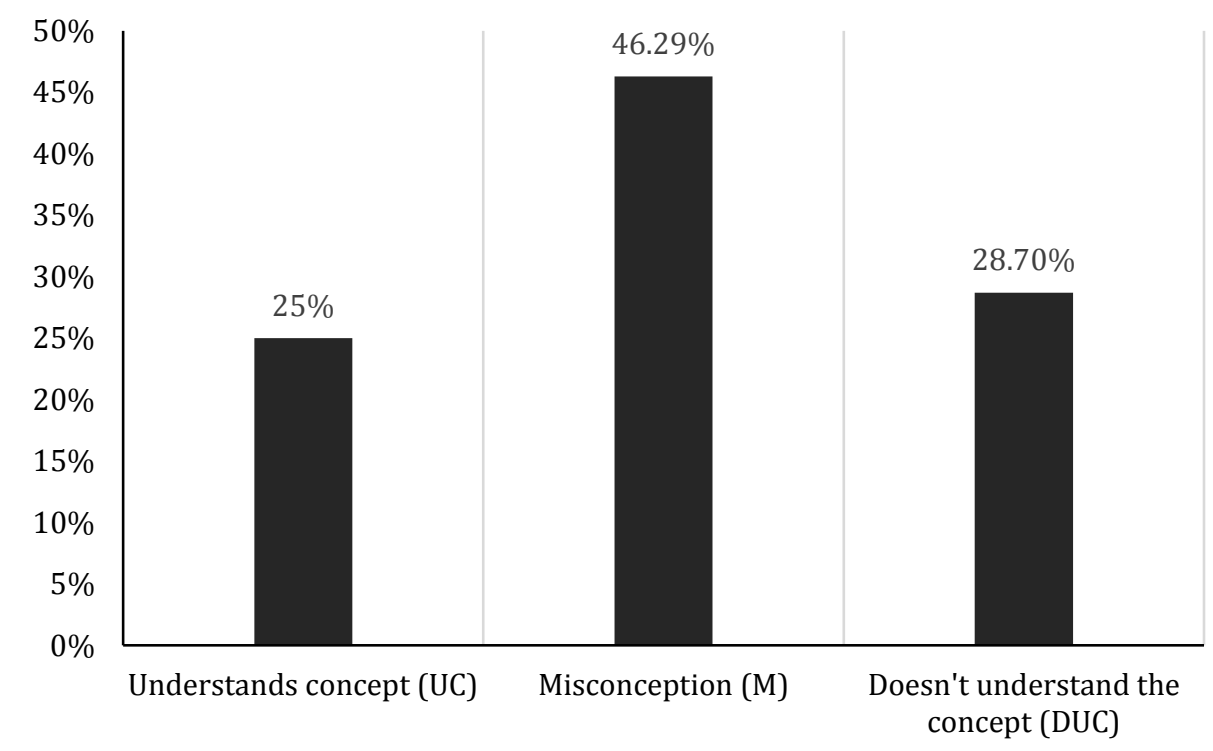

Figure 2. Profile of the prospective Physics teachers' conception

Table 2. The Misconceptions of Prospective Physics Teachers on the Sub-Concept of Friction force Material

\begin{tabular}{|c|c|c|c|c|}
\hline \multirow[t]{2}{*}{ No } & \multirow[t]{2}{*}{ Sub-Concept of Friction force } & \multicolumn{3}{|c|}{$\begin{array}{c}\text { Percentage of Numbers of Prospective Physics } \\
\text { Teachers }(\%)\end{array}$} \\
\hline & & $\mathrm{PK}$ & $\mathrm{M}$ & TPK \\
\hline 1. & Determining the type of friction force & 12,50 & 50,00 & 37,50 \\
\hline 2. & Determining the direction of friction force & 22,92 & 43,75 & 33,33 \\
\hline 3. & Determine the magnitude of the friction force & 36,11 & 47,22 & 16,67 \\
\hline & Total & 25,00 & 46,29 & 28,70 \\
\hline
\end{tabular}


The table above shows that $50.00 \%$ of prospective Physics teachers have misconceptions in determining the type of friction force, $43.75 \%$ have misconceptions in deciding the direction of friction force, and $47.22 \%$ have misconceptions in assessing the magnitude of the friction force on an object. Most students experience misconceptions when they determine the type of friction force acting on moving objects (walking, rotating, and rolling). They believe that when a thing is in motion, the kind of friction force acting on the system of objects is kinetic friction. Of course, this is a common misunderstanding (misconception) that students often experience both at school and at the university level [35].

Based on the results of data analysis, the researchers succeeded in identifying the forms and patterns of misconceptions experienced by prospective physics teachers. The results of this identification can be seen in the following table.

Table 3. Forms and patterns of misconceptions in prospective physics teachers

\begin{tabular}{|c|c|c|c|c|}
\hline \multirow{2}{*}{ Sub-concepts of friction force } & \multirow{2}{*}{ Forms of misconceptions } & \multicolumn{3}{|c|}{ Percentage $(\%)$} \\
\hline & & PK & M & TPK \\
\hline \multicolumn{5}{|c|}{ Determining the type of friction force on a moving and rolling object. } \\
\hline $\begin{array}{l}\text { 1. Determining the type of the friction } \\
\text { force acting on the paws of a walking } \\
\text { cat }\end{array}$ & $\begin{array}{l}\text { - It is a kinetic friction force because the } \\
\text { cat is moving } \\
\text { - It is static friction force because the } \\
\text { friction force acting on the cat's paws } \\
\text { does not slow down the cat's } \\
\text { movement }\end{array}$ & 16,67 & 50,00 & 33,33 \\
\hline $\begin{array}{l}\text { 2. Determining the type of the friction } \\
\text { force acting on a moving bicycle } \\
\text { wheel }\end{array}$ & $\begin{array}{l}\text { - It is a kinetic friction force because the } \\
\text { bicycle wheel is rotating. } \\
\text { - It is a rotational friction force in the } \\
\text { opposite direction to the direction of } \\
\text { the rotation of the wheel }\end{array}$ & 8,33 & 50,00 & 41,67 \\
\hline \multicolumn{5}{|c|}{ Determining the direction of friction force on a moving and rolling object. } \\
\hline $\begin{array}{l}\text { 1. Determining the direction of the } \\
\text { friction force acting on the paws of a } \\
\text { walking cat }\end{array}$ & $\begin{array}{l}\text { - The direction of the friction force is } \\
\text { opposite to the direction of the cat's } \\
\text { movement }\end{array}$ & 16,67 & 58,33 & 25,00 \\
\hline $\begin{array}{l}\text { 2. Determining the direction of the } \\
\text { friction force acting on a moving } \\
\text { bicycle wheel }\end{array}$ & $\begin{array}{l}\text { - The direction of the friction force is } \\
\text { opposite to the direction of the } \\
\text { bicycle's movement } \\
\text { - The direction of the friction force is } \\
\text { forward because the wheels are turning } \\
\text { backwards } \\
\text { - The direction of the frictional force } \\
\text { rotates in the opposite direction to the } \\
\text { direction of rotation of the wheel }\end{array}$ & 25,00 & 50,00 & 2500 \\
\hline $\begin{array}{l}\text { 3. Determining the direction of the } \\
\text { friction force acting on the wheels of } \\
\text { a toy car that is being pulled until the } \\
\text { car moves }\end{array}$ & $\begin{array}{l}\text { - The direction of the friction force is } \\
\text { forward because the wheels are turning } \\
\text { backwards } \\
\text { - The direction of the friction force } \\
\text { rotates opposite to the direction of the } \\
\text { rotation of the wheel }\end{array}$ & 33,33 & 33,33 & 33,33 \\
\hline $\begin{array}{l}\text { 4. Determining the direction of the } \\
\text { friction force on a rolling wheel }\end{array}$ & $\begin{array}{l}\text { - The direction of the friction force is } \\
\text { forward because the wheels are turning } \\
\text { backwards } \\
\text { - The direction of friction force is } \\
\text { opposite to the direction of the rotation } \\
\text { of the wheel }\end{array}$ & 16,67 & 33,33 & 50,00 \\
\hline \multicolumn{5}{|c|}{ Determining the magnitude of friction force on a static or moving object. } \\
\hline $\begin{array}{l}\text { 1. Determining the magnitude of the } \\
\text { friction force on an object that is } \\
\text { being pushed forward but remains } \\
\text { quiescent }\end{array}$ & $\begin{array}{l}\text { - The friction force is greater than the } \\
\text { thrust, this is what causes the object to } \\
\text { remain quiescent }\end{array}$ & 16,67 & 75,00 & 8,33 \\
\hline 2. Determining the magnitude of the & - The thrust is greater than the friction & 50,00 & 41,67 & 8,33 \\
\hline
\end{tabular}




\begin{tabular}{|c|c|c|c|c|c|}
\hline & $\begin{array}{l}\text { friction force on an object that is } \\
\text { being pushed forward with constant } \\
\text { velocity }\end{array}$ & $\begin{array}{l}\text { force, this is what causes the object to } \\
\text { move }\end{array}$ & & & \\
\hline 3. & $\begin{array}{l}\text { Determining the magnitude of the } \\
\text { friction force of a quiescent object if } \\
\text { the coefficients of static and kinetic } \\
\text { friction are known. }\end{array}$ & $\begin{array}{l}\text { - The magnitude of the static and kinetic } \\
\text { friction forces can be determined by } \\
\text { the equation: } \\
\mathrm{f}_{\mathrm{s}}=\mu_{\mathrm{s}} \mathrm{N} \text { dan } \mathrm{f}_{\mathrm{k}}=\mu_{\mathrm{k}} \mathrm{N}\end{array}$ & 41,67 & 25,00 & 33,33 \\
\hline
\end{tabular}

Based on the data in Table 2 and Table 3 above, it can be seen that in determining the type of friction force, $\quad 50.00 \%$ of students experienced misconceptions, $37.50 \%$ did not understand the concept and only $12.50 \%$ of them understood the concept. This can be seen when they determine the type of friction force acting on the paws of a walking cat, $50.00 \%$ of them experienced misconceptions in this case. Most of those who have misconceptions said that the type of friction that acts on the cat's feet is kinetic friction because the cat is moving. Similarly, when students were instructed to determine the type of friction force on a moving bicycle wheel, $50.00 \%$ of them experienced misconceptions. Some of those who experience misconceptions believe that the type of friction force acting on a bicycle wheel is kinetic friction because it is rotating.

The form of students' answers to these two questions gives us information that; students still do not really understand specifically the definition of static and kinetic friction force. The concept embedded in their cognition is only limited to "if the object is moving then the object acts on the kinetic friction force and vice versa, if the object is quiescent then the friction force acting on the surface of the object is static friction force". However, the problem is that students do not really understand the meaning of the words "moving " and "quiescent" in the definition above, even though all students know the definitions of static and kinetic friction force. The students show an object as a system. When the system is moving (in this case the cat and bicycle are seen as a system), then kinetic friction force is acting on it. While, the meaning of the word "moving " or "quiescent" in the above definitions is the relative motion/movement between two momentary things when they intersect. For example, when considering the interaction between the cat's paws and the floor surface, if the cat walks without slipping, the cat's paws are relatively quiescent to the floor; just when the cat's paws are in contact with the floor, the static friction force acts. Furthermore, on the cases of the movement of the bicycle wheel moving on the asphalt, even though the bicycle wheel is rotating, if taking a deeper observation on the relative motion between the bicycle wheel and the asphalt, it can be seen that the surface of the wheel is relatively quiescent to the asphalt for a moment when the surface of the wheel is in contact with the asphalt.
Therefore, the correct answer is that the static friction force acts on a bicycle wheel.

In determining the direction of friction force on objects, $43.75 \%$ of the students experience misconceptions. This can be seen when students are instructed to determine the direction of the friction force on the paws of a moving cat, the wheel of a rolling bicycle, and the wheels of a moving toy car (without an engine). The pattern of student answers is in line with their answers when determining the type of friction force on an object. Most of the students experience misconceptions because they see an object or objects systematically, as can be seen when determining the direction of the friction force on the paws of a moving cat. $58.33 \%$ of the students experienced misconceptions. They assume that the direction of the friction force acting on the cat's paws towards the back is opposite to the direction of the cat's movement. Similarly, when they determine the direction of the friction force acting on the wheel of a bicycle. $50.00 \%$ of the students have misconceptions. $63.33 \%$ of those who experience misconceptions believe that the direction of the friction force acting on the wheel of the bicycle is towards the opposite to the direction of the movement of the bicycle and $36.67 \%$ of them think that the direction of the friction force is counterclockwise because the wheel rotates clockwise. When students determine the direction of the friction force acting on the wheels of the toy car and the wheels that are rolling, similarly, most of those who experience misconception believe that the direction of friction force is opposite to the direction of rotation of the wheel.

After conducting interview, it was confirmed that the students' answers, the reason they answered was because one of the characteristics of the friction force was opposite to the direction of the object's movement. If the object is moving forward then the friction force acting on the object must be backwards. Moreover, when an object moves in a clockwise direction, the direction of the friction force of the object will be opposite to the direction of rotation, which is counterclockwise.

In fact, the student's conception which states that the direction of the friction force is always opposite to the direction of the force or the direction of movement of objects is correct. It's just as explained earlier that they are still looking at objects macroscopically (systems of objects). Their view is not focused on the surface of the object that is in contact. For example, when looking at the paws of a 
cat that is walking without slipping, the object that should be the focus of observation is the object that touches (the sole of the cat's paw with the floor surface), not the movement of the cat as a whole. When the cat moves forward, the cat's paws lean back on the floor so that the floor reacts forward. In this case, this reaction force acts as a friction force so that its direction also follows the direction of the reaction force (forward). Similarly, on the rear wheel of the bicycle, when the bicycle is pedaled, it will cause the bicycle wheel to rotate (assume the direction of rotation of the bicycle is clockwise). If we look at the form of interaction between the surface of the bicycle wheel and the asphalt, then when it rotates, the wheel gives the asphalt surface a push towards the back. At that time, of course the asphalt surface will react in the form of a push to the wheel surface towards the front. This action force acts as a friction force on the surface of the wheel. The following is an example of a form of misconception experienced by prospective Physics teachers in terms of determining the direction of the friction force acting on an object.

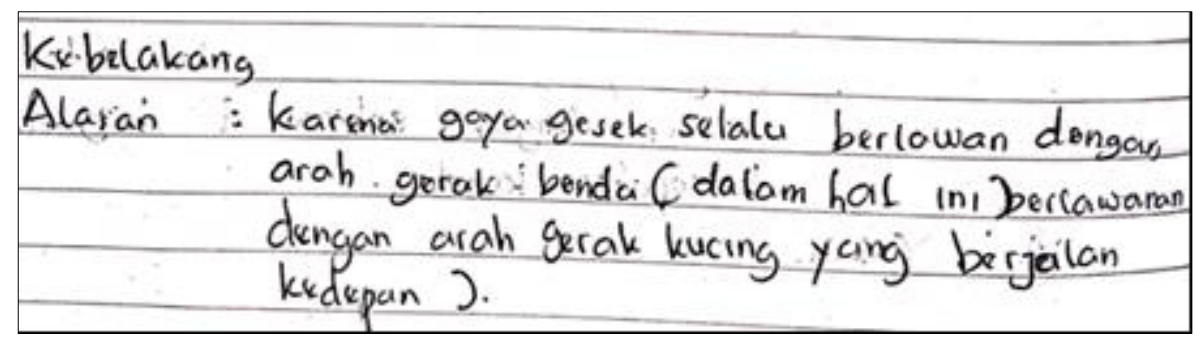

(a)

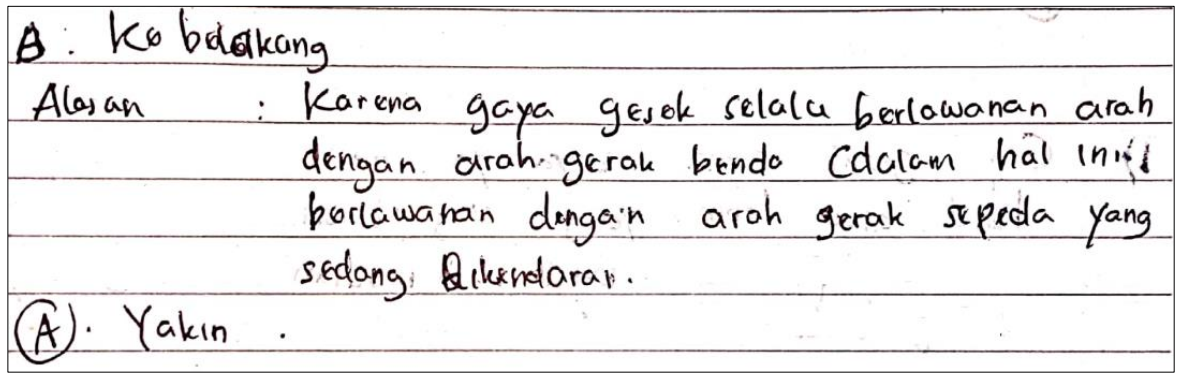

(b)

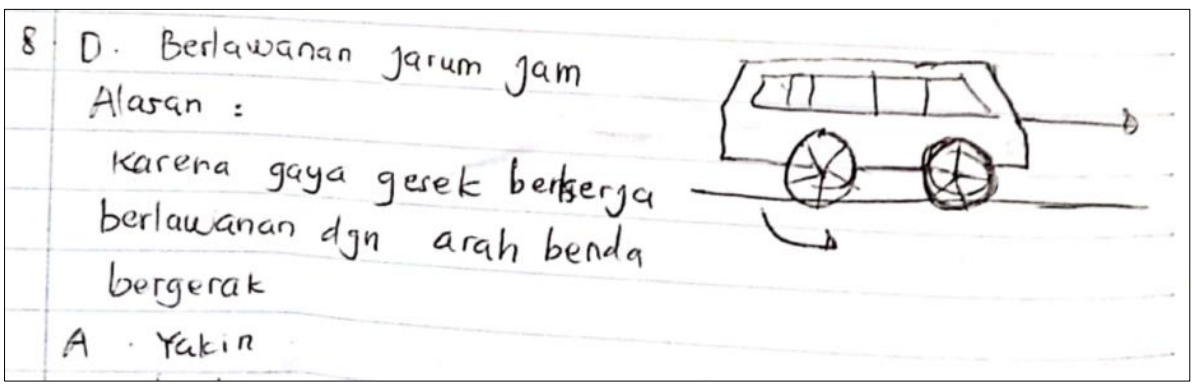

(c)

Figure 3. Examples of student answers in determining the direction of the friction force on (a) cat paws, (b) bicycle wheels, (c) toy car wheels

Next discussion is about the shape and pattern of students' misconceptions in determining the amount of friction force on an object. Based on the data in table 2 and table 3 , it can be seen that, $47.22 \%$ of students experienced misconceptions. This can be seen when students determine the magnitude of the friction force acting on a cupboard that is pushed, but the cupboard remains quiescent (not move); $75 \%$ experienced misconceptions in this case. Almost all students who experience misconceptions think that the magnitude of the friction force acting on the object is greater than the thrust. It is what causes the object to remain quiescent.

Similarly, when they were instructed to determine the magnitude of the friction force experienced by the object being pushed, making the object move at a constant speed, $41.67 \%$ of students experienced misconceptions. They assume that the magnitude of the friction force acting on the object is smaller than the thrust. Furthermore, when 
J. Pijar MIPA, Vol. 16 No.5, November 2021: 650-658 DOI: $10.29303 /$ jpm.v16i5.1448

interviewed, students were given follow-up questions:

"If you say that an object is quiescent when it is pushed, it means that the friction force acting on the object is greater than the thrust $\left(f_{\text {ges }}>F\right)$, then does it indicate that the resulting object is not zero? $\left(\sum F\right.$ $\neq 0)$...?"
ISSN 1907-1744 (Print)

ISSN 2460-1500 (Online)

Some of the students could not answer this question. It is indicated that students also do not seem to really understand Newton's laws. Therefore, it is necessary to conduct further studies in this regard. The following is an example of a misconception experienced in determining the magnitude of the friction force on an object.

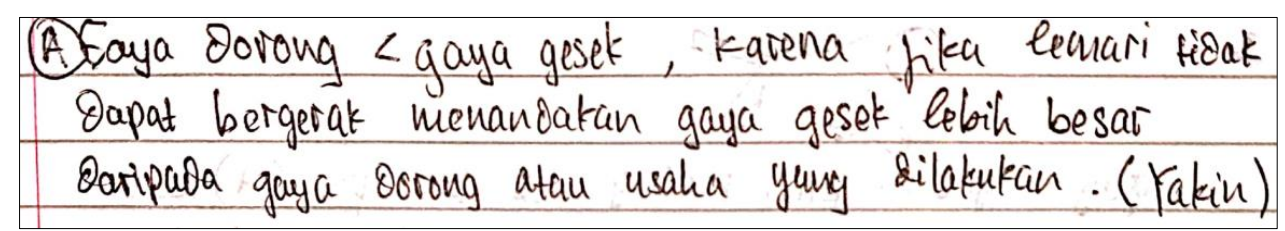

(a)

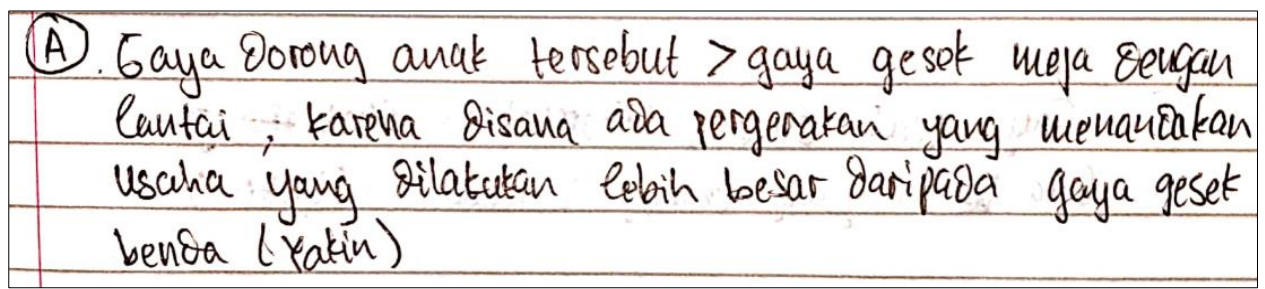

(b)

Figure 4. Examples of student answers in determining the magnitude of the friction force on object that is (a) quiescent (not moving), (b) moving with constant velocity

Based on the results of data analysis as described above, it can be seen that students have not been able to understand the concept of friction force as a whole well and in-depth. It is an indicator that the learning process applied so far is less effective in reducing misconceptions that occur in students.

\section{CONCLUSION}

Based on the results of the data analysis described above, it can be concluded that there are still many prospective Physics teachers who have misconceptions about the concept of friction force. It is an indicator that the learning process applied in higher education is still less effective in reducing misconceptions that occur in students. Therefore, it is necessary to innovate in learning to find learning alternatives that can be used to minimize misconceptions experienced by prospective Physics teachers.

\section{REFERENCES}

[1] Cepni, S., Ulger, B. B. \& Ormanci, U., (2017). Pre-service science teachers' views towards the process of associating science concepts with everyday life. Journal of Turkish Science Education, 14 (4). 1-15, doi: 10.12973/tused.10208a
[2] Rokhmat, J., Marzuki, dan Wahyudi, (2019). Fisika SMA-1a dengan Pendekatan Berpikir Kausalitik. Mataram: LITPAM,

[3] Gurel, D., Eryilmaz, A. \& McDermott, L., (2017). Development and application of a four-tier test to assess pre-service physics teachers' misconceptions about geometrical optics. Research in Science and Technological Education, 35(2). 238-260, doi: 10.1080/02635143.2017.1310094

[4] McLaughlin, C. A. \& MacFadden B. J., (2014). At the Elbows of Scientists: Shaping science teachers' conceptions and enactment of inquiry-based instruction. Research in Science Education, 44 (6). 927-947 doi:10.1007/s11165-014-9408-Z

[5] Solas, E. C. \& Wilson, K., (2017). Instructor's use of student-generated annotated concept sketches in formative assessment in general science. Journal of Turkish Science Education, 14 (4). 144-161 doi:10.12973/tused.10217a

[6] Samsudin, A., Fratiwi, N. J., Kaniawati, I., Suhendi, E., Hermita, N., Suhandi, A., Wibowo, F. C., Costu, B., Akbardin, J. \& Supriyatman S., (2017). Alleviating Students' Misconceptions About Newton's First Law Through Comparing PDEODEE Tasks and POE Tasks: Which is More 
Effective?" The Turkish Online Journal of Educational Technology, Special Issue for INTE 2017, 215-221, October 2017a.

[7] Osman, E., BouJaoude, S. \& Hamdan, H., (2017). An investigation of lebanese G7-12 students' misconceptions and difficulties in genetics and their genetics literacy. International Journal of Science and Mathematics Education, $15 \quad$ (7). 1257-1280 https://eric.ed.gov/?id=EJ1154243

[8] Pratama, S., Al Idrus, A. A. I., Kusmiyati, K., \& Setiadi, D. (2021). Identifikasi Pemahaman Konsep Sistem Reproduksi dengan Menggunakan Instrumen Three Tier Test di Lombok Barat. Jurnal Pijar Mipa, 16(1), 30-38.

[9] Turgut, U., Gurbuz, F., \& Turgut, G., (2011). An investigation 10th grade students' misconceptions about electric. Procedia Social and Behavioral Sciences 15), 1965-1971

[10] Maesyarah, M., Jufri, A. W., \& Kusmiyati, K. (2015). Analisis penguasaan konsep dan miskonsepsi biologi dengan teknik modifikasi certainty of response index pada siswa SMP sekota Sumbawa Besar. Jurnal Pijar Mipa, 10(1).

[11]Fadllan, A., Prawira, W.Y., Arsini, \& Hartono, (2019). Analysis of students' misconceptions on mechanics using three-tier diagnostic test and clinical interview. Journal of Physics: Conf. Series 1170. 1-5.

[12] Ammase, A., Siahaan, P., dan Fitriani, A., (2018). Identification of junior high school students' misconceptions on solid matter and pressure liquid substances with four tier-test. International Conference on Mathematics and Science Education (ICMScE 2018). doi:10.1088/1742-6596/1157/2/022034

[13] Maharani, L., Rahayu, D.I., Amaliah, E., Rahayu, R., \&, Saregar, A., (2019). Diagnostic Test with Four-Tier in Physics Learning: Case of Misconception in Newton's Law Material," Journal of Physics: Conf. Series. 1-8. doi:10.1088/1742-6596/1155/1/012022. 1-8

[14] Sari, D.R., Ramdhani, R , Surtikanti, H.K., (2018). Analysis of elementary school students' misconception on force and movement concept. International Conference on Mathematics and Science Education (ICMScE 2018)

[15] Murti, P.R., Aminah, N.S., \& Harjana, (2019). The identification of high school students' knowledge of newton's law of science literacy using a test based on nature of science (NOS). 9th International Conference on Physics and Its Applications (ICOPIA), doi:10.1088/17426596/1153/1/012122

[16] Wahyuni, A.S.A., Rusdiana, D., Rustaman, N., Muslim, (2018). Paper Conceptions and Misconceptions of PreService Teacher about Light. International Conference on Advanced Multidisciplinary Research (ICAMR). 227(1).
56-60, doi: https://doi.org/10.2991/icamr18.2019 .15

[17] Ismail, I. I., Samsudin, A., Suhendi, E., Kaniawati, I., (2015). Diagnostik Miskonsepsi Melalui Listrik Dinamis Four Tier Test. Prosiding Simposium Nasional Inovasi dan Pembelajaran Sains (SNIPS 2015), Bandung, Indonesia. 381-384,

[18] Lestari, P.A.S., Rahayu, S., Hikmawati, (2015). Profil Miskonsepsi Siswa Kelas X SMKN 4 Mataram pada Materi Pokok Suhu, Kalor, dan Perpindahan Kalor. Jurnal Pendidikan Fisika dan Teknologi. 1 (3). 146153. ISSN. 2407-6902

[19] Barke, H.D., Al Hazari, Yitbarek, S.,(2009). Misconceptions in Chemistry. Addressing Perceptions in chemical education. Berlin: Springer

[20] Busyairi, A., Rokhmat, J., \& Verawati, (2021). Penggunaan Paradigma Gaya Gesek Sebagai Gaya Reaksi Untuk Mereduksi Miskonsepsi Mahasiswa Calon Guru Fisika. Jurnal Ilmiah Profesi Pendidikan, 6 (1). $66-73$ doi: https://doi.org/10.29303/jipp.v6i1.154

[21]Liampa, V., Malandrakis, G. N., Papadopoulou, P. \& Pnevmatikos, D., (2017). Development and evaluation of a three-tier diagnostic test to assess undergraduate primary teachers' understanding of ecological footprint. Research in Science Education, 1-26, doi: 10.1007/s11165-017-9643-1

[22] Chen, F., Zhang, S., Guo, Y. \& Xin, T., (2017). Applying the rule space model to develop a learning progression for thermochemistry. Research in Science Education, 47 (6).1357-1378. doi: 10.1007/s11165-016-9553-7

[23] Purwanto, M. G., Nurliani, R., Kaniawati, I. \& Samsudin, A., (2018). Promoting the Hydrostatic Conceptual Change Test (HCCT) with four-tier diagnostic test item. Journal of Physics:Conference Series, 1013, $1-6$.

[24] Mainali, B \& Heck, A., (2017). Comparison of traditional instruction on reflection and rotation in a nepalese high school with an ICT-Rich, student-centered, investigative approach. International Journal of Science and Mathematics Education, 15 (3). 487507. doi: 10.1007/s10763-015-9701-y

[25] Samsudin, A., Suhandi, A., Rusdiana, D., Kaniawati, I. \& Costu, B., (2015). Fields conceptual change inventory: a diagnostic test instrument on the electric field and magnetic field to diagnose student's conceptions. International Journal of 
Industrial Electronic Engineering, 3

(12). 74-77. ISSN: 2347-6982

[26] Poutot, G. \& Blandin, B., (2015). Exploration of students' misconceptions in mechanics using the FCI. American Journal of Educational Research, 3 (2). 116-120, doi: 10.12691/education-3-2-2

[27] Gurel, D., Eryilmaz, A., \& McDermott, L., (2015). A review and comparison of diagnostic 1nstruments to 1dentify students' misconception in science. Eurasia Journal of Mathematics, Science \& Technology Education, 11 (5). 989-1008,

doi: 10.1080/02635143.2017.1310094

[28] Adams, W \& Wieman, C., (2010). Development and validation of instruments to measure learning of expert-like thinking. International Journal of Science Education, 1-24,

[29] Kaniawati, I., Fratiwi, N.J.,, Danawan A., Suyana, I, Achmad Samsudin, A., \& Suhendi, E., (2019). Analyzing Students' Misconceptions about Newton's Laws through Four-Tier Newtonian Test (FTNT). Journal of Turkish Science Education, 16 (1)

[30] Pesman, H \&Eryilmaz, A., (2010). Development of a three-tier test to assess misconceptions about simple electric circuits. The Journal of Educational Research, 103. 208-222

[31] Saat, R., Fadzil, H., Aziz, N., Haron, K., Rashid, K., Shamsuar, N., (2016). Development of an Online Three-Tier Diagnostic Test to Assess Pre-University Students' Understanding of Cellular Respiration. Journal of Baltic Science Education, 15 (4). 532-546. doi: $10.33225 / \mathrm{jbse} / 16.15 .532$

[32] Musfiqon, H. M., (2012). Panduan Lengkap Metodologi Penelitian Pendidikan. Jakarta: Prestasi Pustakarya

[33] Sugiyono, (2012). Statistika Untuk Penelitian. Bandung: Alfabeta

[34] Arslan, H. O., Cigdemoglu, C., Moseley, C., (2012). A Three-Tier Diagnostic Test to Assess Pre-Service Teachers' Misconceptions about Global Warming, Greenhouse Effect, Ozone Layer Depletion, and Acid Rain. International Journal of Science Education, 34 (11).16671686, doi: 10.1080/09500693. 2012.680618

[35] Hikmawati, \& Sutrio, (2019). Miskonsepsi dalam Fisika. Selong: Garuda Ilmu 